“Institutional aspects of the social enterprises' sector development (case for Poland and Ukraine)"

\begin{tabular}{|c|c|c|}
\hline AUTHORS & Oleksandr Lyakh & \\
\hline ARTICLE INFO & $\begin{array}{l}\text { Oleksandr Lyakh (2017). Institut } \\
\text { development (case for Poland a } \\
\text { 1(1), 17-29. doi:https://doi.org/10 }\end{array}$ & $\begin{array}{l}\text { social enterprises' sector } \\
\text { olitics under Globalization, } \\
17.03\end{array}$ \\
\hline DOI & https://doi.org/10.21511/gg.01(1 & \\
\hline JOURNAL & "Geopolitics under Globalizatior & \\
\hline ISSN PRINT & $2543-5493$ & \\
\hline PUBLISHER & Sp. z o.o. Kozmenko Science P & \\
\hline FOUNDER & Sp. z o.o. Kozmenko Science P & \\
\hline$\sigma^{\circ}$ & 15 & $\begin{array}{l}\text { ニニ } \\
\text { ニこ }\end{array}$ \\
\hline NUMBER OF REFERENCES & NUMBER OF FIGURES & NUMBER OF TABLES \\
\hline 39 & 1 & 2 \\
\hline
\end{tabular}

(C) The author(s) 2023. This publication is an open access article. 
Oleksandr Lyakh (Ukraine)

\title{
Institutional aspects of the social enterprises' sector development (case for Poland and Ukraine)
}

\begin{abstract}
The potential contribution of social enterprises to work integration, job creation, and service delivery remains largely unrealized both in Poland and Ukraine. This paper focuses on the analysis of the role of social economy and social enterprises sector in providing employment opportunities and wide range of services for group of interest. One of the major obstacles to the discussion and study of the topic is the lack of a clear and concise definition. It is requiring investigating evolution of social enterprise as a concept and as a sector of the Polish and Ukrainian economies. Institutional aspects and legal frameworks are considered in order to define the appropriate eco-system for social enterprises sector support and fostering. Attention was also paid to frame of the policy for social enterprises support and ongoing decentralization of public authority that is allowing to clarify what level of authority should be responsible for concrete policy measures elaborating.
\end{abstract}

Keywords: social enterprises, cooperatives, collective entrepreneurship, social goals, social entrepreneurship and social innovation policies, legal frameworks and institutions for social enterprises support, Poland and Ukraine.

JEL Classification: L38, P13.

\section{Introduction}

Global challenges to economic, social and environmental sustainability triggered by tough competition in foreign and domestic markets have prompted increased efforts to find alternative strategies for development. In the official documents and social sciences literature devoted to the issues of contemporary socio-economic development one can find conclusion that economic activity should acquire more social features (European Commission, 2013; Fitoussi, J.-P., Stiglitz, J., 2011; Driver, M., Porter, M., 2012). Now new concepts and theories regarding reconsideration of interaction between society and corporate performance and the emergence of new forms of social orientation of business are occurring and gaining the recognition to be considered as part of a broader set of competitiveness and development theories. Significantly, the recognized management gurus Michael Porter and Mark Kramer (2011) revised their traditional outlook on the core competencies of a company and its competitive strategies based on the priority of value for its shareholders. Instead, they put forward the concept of shared value, according to which not only the shareholders have to benefit from growth of profit and enterprise value, but also society as a whole. They suggest that the competitiveness and prosperity of the communities in which business operates are interdependent, and that perhaps the recognition and use of the interdependence between

(C) Oleksandr Lyakh, 2017.

Oleksandr Lyakh, Ph.D., Leading Researcher, Department of Regulatory Policy and Entrepreneurship Development Issues, Institute of Industrial Economics of National Academy of Sciences of Ukraine, Ukraine. social and economic progress is the basis for the next phase of global economic growth.

There is a growing global movement to advance concepts and frameworks of social entrepreneurship as one of the ways to address increasing inequality of social, health, economic and ecological conditions, to provide alternative solutions to the perceived failure of neo-liberal dominated globalization. Social entrepreneurship and social enterprises (as its organizational form) broadly recognized as a new approach for mitigating unemployment, poverty, lack of public finances for social services providing (European Commission, 2011; Spear, R. et al., 2001; Defourny, J., Favreau, L., Laville, J.-L., 2001; Quak, E., 2013). Research and practical measures aimed to create favorable institutional frameworks and appropriate ecosystem for social entrepreneurship fostering are of great importance for former socialist countries (Bibikova, V., 2015; Cahalane, C., 2011; Kaderabkova, A., 2013; Kusa, R., 2012). The niche for the development of social enterprises in Ukraine is significant. It is due to "...the existence of a complex web of conflicting trends in the field of social, labor and human development" (Kolot, A., Herasymenko, O., 2016, p. 8), "... most especially in the presence of the systematic retreat of the governments from the provision of public goods in the face of new political ideologies that stress citizens' selfsufficiency and give primacy to market-driven models of welfare" (Nicholls, A., 2006, p. 1). Therefore, the experience of neighboring countries to create conditions for development of the sector of social enterprises in order to tackle the pressing social and economic issues in Ukraine is valuable. 
The purpose of this paper is to analyze the evolution of the social enterprise concept on the basis of the existing literature in this subject area and focuses on the legal implementation and institutional frameworks of social enterprises in Poland and Ukraine.

\section{Methodology and research approach}

To gain a thorough understanding of its facets, and to build up a solid and tested framework for the comparative part, the concept of social entrepreneurship and enterprises is explored through a literature review of current research of leading scholars on this topic initially. Then, ways to enhance the development of social enterprises are determined on the basis of a study of available empirical data, scientific literature, laws and regulations relating to the ecosystem for the appearance and operation of social enterprises in both countries. Conclusions are on how the social enterprise concept has been legally implemented and institutions necessary for social entrepreneurship support established in Poland and Ukraine. In doing that a number of general and special methods were used, such as: theoretical generalization, abstract logic; synthesis; comparative and structural analysis.

\section{Revising the literature on social entrepreneurship and social enterprise}

The clusters of business entities and persons registered as social enterprises or social entrepreneurs have been referring in official documents, analytical reports, academic papers and reflecting in the statistics of different countries as a part of separate economic sector under the name: social economy (European Union, Francophone Canada), solidarity economy (Latin America), people's economy (Pacific Asia), associative movements (Muslim countries), civil society economy (South Africa), and community economic development (Australia, Anglophone Canada, New Zealand, USA). What distinguishes social enterprises from such traditional subjects of social economy sector as consumer cooperatives, associations or charities is the fact that social enterprises are earning a substantial proportion of their funding through trading of its products or services, rather than being dependent on grants or donations. A benchmark sometimes used for a social enterprise is that at least $50 \%$ of its turnover is earned income, although opinions vary on what the best threshold would be. In any event, what distinguishes social enterprises from conventional enterprises is that they have a primary social purpose (European Economic and Social Committee, 2013).

The phenomenon of social entrepreneurship and enterprise emerged long before its theoretical generalization as a practical activity due to development of the cooperatives movement and evolution of the third sector (NGOs) towards commercialization and involvement into public service provision, as well as in rare cases in result of spin-off of social activity and related assets from business corporations.

The concept of social enterprises have been widely discussed in academic circles and literature mainly in the OECD countries since the early 90s of the last century (Defourny, J., Nyssens, M., 2010). Since then, the social enterprises have found strong enough recognition in academic and political circles, reflected in the curricula of universities and business schools, entrenched in the legislation of individual countries and in the regulations of the European Union, as well as appropriate public agencies for support this business have been created. Various private foundations have launched training and support programmes for social enterprises or sole entrepreneurs oriented on social issues. Moreover, there were research centres for social enterprises initiated in many countries and international ones under umbrellas of the OECD office (Centre for Entrepreneurship, SMEs and Local Development) and European Commission (European Research Network EMES). The latter has been established formally as a non-profit association (ASBL under Belgian law) in 2002 and named after its first research program in 1996-2000 on "The emergence of social enterprises in Europe" (henceforth EMES). EMES was originally composed of European university research centres and individual researchers. After several years of collaborative research and projects jointly conducted with researchers from other regions, EMES has decided in 2013 to open its membership to researchers from around the world (see: http://emes.net/who-we-are/). In 2001 nine leading Latin-American business schools, Spanish business school Escuela Superior de Administración y Dirección de Empresas and the Harvard Business School established the Social Enterprise Knowledge Network (henceforth SEKN). The product of SEKN teamwork, Effective Management of Social Enterprises, is "path-breaking in capturing and analyzing smart social enterprise practices in Latin America" (SEKN, 2006).

Now the concepts of social economy, social entrepreneurship and social enterprise are attracting many scholars and policy makers in wide range of 
societal sciences (sociology, political studies, economics, and management) which are showing a clear research interest more than a decade later in order to address to modern social challenges. The research activities were concentrated on such topics as reasons for emerging and evolution of the social economy as well as its role and concrete areas for support of socio-economic sustainable development (Spear, R. et al., 2001; Borzaga, C., Galera, G., Nogales, R., 2008; Defourny, J., Nyssens, M., 2010; Pestoff, V., Drandsen, T., Verschuere, B., 2011), legal, financial and organizational issues of diverse legal forms of the social economy subjects functioning (Mendell, M., 2007; OECD, 2010; European Center for Not-for-Profit Law, 2012; Defourny, J., Nyssens, M., 2016). Recently in publications on the topic a clear emphasis is made on connection of social enterprises and entrepreneurship with innovation activity (Buscaglia, F., Marini, M., Tarantola, G., 2007; Defourny, J., Nyssens, M., 2013; Sotula, O.V., 2013; Borzaga, C., Bodini, R., 2014; Grisolia, F., Ferragina, E., 2015)

The development of social enterprises and corporate social responsibility are the constituent parts of such a concept as social entrepreneurship, that "...blurs traditional boundaries between institutional sectors, public and private, types of innovations, and their creators and users" (Kaderabkova, A., 2013). Under that one can define social entrepreneurship narrowly, as European Economic and Social Committee (2013) done, - it is the business activity that aimed to unsolved social issues in which profits served as a tool to achieve social goal. The OECD Centre for Entrepreneurship, SMEs and Local Development gives broader definition (OECD, 2010, p. 223): "Social entrepreneurship - a type of entrepreneurship that aims to provide innovative solutions to unsolved social problems and challenges. It often goes handin-hand with social innovation processes. Social entrepreneurs organize themselves across a wide spectrum of organizations which have an entrepreneurial approach and whose primary mission is to tackle social problems and generate radical or more limited social changes. Social entrepreneurship is therefore about solving social problems rather than exploiting market opportunities in order to maximize profits".

In Europe, despite the absence of universal and indisputable definition of the social enterprise, this concept has been increasingly using to identify an alternative way of doing independent business, which occurs when an enterprise created in order to pursue primarily social aims while simultaneously carrying out commercial activities. Thus, a social enterprise differs from the phenomenon called corporate social responsibility (CSR) because of the priority goals pursued by the owners or creators of the company. In the case of CSR, social outcomes are secondary and often with the main objective to increase the company's image, while social enterprises resorting to commercial activity primarily to ensure financial stability for social activities.

The European Commission gives to the term "social enterprise" the following meaning: "an operator in the social economy whose main objective is to have a social impact rather than make a profit for their owners or shareholders. It operates by providing goods and services for the market in an entrepreneurial and innovative fashion and uses its profits primarily to achieve social objectives. It is managed in an open and responsible manner and, in particular, involves employees, consumers and stakeholders affected by its commercial activities" (European Commission, 2011).

Instead of seeking "an elegant short definition", the EMES European Research Network prefer a conceptual approach for social enterprises definition based on the selection of nine indicators into three dimensions (Defourny, J. and Nyssens, M., 2013, pp. 44-46):

(1) the economic and entrepreneurial dimension:

- a continuous activity producing goods and/or selling services;

- a significant level of economic risk;

- a minimum amount of paid work;

(2) the social dimension:

- an explicit aim to benefit the community;

- an initiative launched by a group of citizens or civil society organizations;

- a limited profit distribution: the primacy of the social aim is reflected in a constraint on the distribution of profits;

(3) the governance dimension:

- a high degree of autonomy;

- a decision-making power not based on capital ownership;

- a participatory nature of governance, which involves various stakeholders affected by the activity of an enterprise.

The European Economic and Social Committee (2013, p. 2) share this position: "The EESC understands that a clear definition is needed so that efforts can be focused, but rather than a definition, 
proposes a description based on shared characteristics such as:

- having primarily social objectives as opposed to profit objectives, producing social benefits that serve the general public or its members;

- being primarily not-for-profit, with surpluses principally being reinvested and not being distributed to private shareholders or owners;

- having a variety of legal forms and models: e.g. cooperatives, mutuals, voluntary associations, foundations, profit or non-profit companies; often combining different legal forms and sometimes changing form according to their needs;

- being economic operators that produce goods and services (often of general interest), often with a strong element of social innovation;

- operating as independent entities, with a strong element of participation and codecision (staff, users, members), governance and democracy (either representative or open);

- often stemming from or being associated with a civil society organization."

3. The value of social economy and social enterprises in social and economic development of the EU

Regardless of the definition of social enterprise, it comprises such legal forms of enterprises as sole proprietorship, cooperative, association, foundation, mutual benefit and voluntary organizations, charity (European Center for Not-for-Profit Law, 2012). Despite their diversity, social enterprises provide social services and contribute to integration of unemployed and disabled people to work (e.g. training and integration of unemployed persons) thus assisting in the development of disadvantaged areas (especially remote rural and economically distressed areas). While empirical evidence shows that social entrepreneurship is growing in many countries, measuring it - like measuring the social economy, the third sector and the non-profit sector is difficult. This is due not only to the variety of the entities belonging to the field, but also to the fact that these entities vary according to the geographical context and to the fact that different countries recognize social entrepreneurship differently (OECD, 2010).

The survey of social economy enterprises (cooperatives, associations, foundations, mutual benefit and voluntary organizations, charities) in European Union has been conducted in 2013 (unfortunately, such a survey exactly for social enterprises couldn't be performed due to methodological differences in the statistical reporting of these enterprises in different countries). In order to ensure comparability in comparing countries, the number of enterprises were divided by the number of people in these countries (see Figure 1).

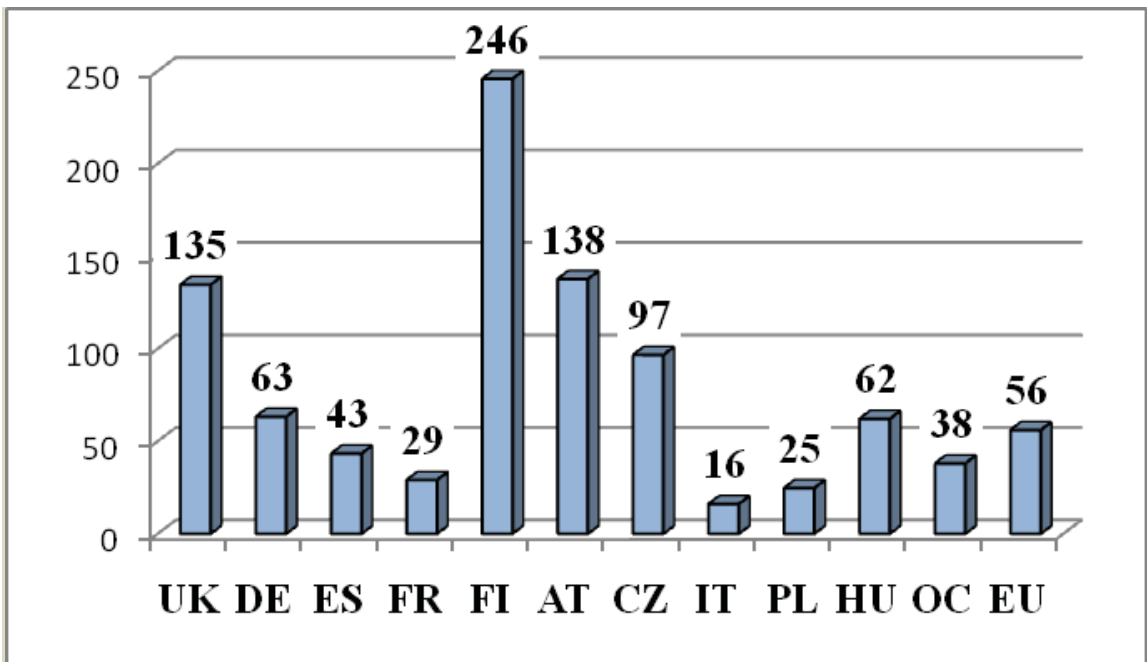

Fig. 1. Number of social economy enterprises per 10 thousand inhabitants in EU

\begin{tabular}{|l|c|l|c|}
\hline \multicolumn{4}{|c|}{ Abbreviated names of countries } \\
\hline Austria & AT & Italy & IT \\
\hline Czech Republic & CZ & Poland & PL \\
\hline Finland & FI & Spain & ES \\
\hline France & FR & United Kingdom & UK \\
\hline Germany & DE & Other countries & OC \\
\hline Hungary & HU & The EU average & EU \\
\hline
\end{tabular}


Calculations are based on: http://europa.eu/abouteu/countries/member-countries/;

http://ec.europa.eu/social/keyDocuments.jsp?pager.off set $=20 \&$ langId $=$ en $\&$ mode $=$ advancedSubmit $\&$ year $=0$ $\&$ country $=0 \&$ type $=0 \&$ advSearchKey $=$ socententryrept s\&orderBy $=$ docOrde.

The results presented in Figure 1 show dramatic discrepancy in representativeness of such enterprises in the countries' economies. The most rapidly the social economy sector was growing in Finland, Austria and the UK, among the countries that joined the EU last - in the Czech Republic. Indicators of Poland were the lowest among the countries surveyed and more than two times lower than the average in the European Union.

According to web site of European Commission on 20/11/2016 (see: https://ec.europa.eu/growth/sectors/socialeconomy_en.), there are 2 million of social economy enterprises in Europe, representing $10 \%$ of all businesses in the EU. More than 11 million people about $6 \%$ of the EU's employees - work for social economy enterprises: out of these, $70 \%$ are employed in non-for-profit associations, $26 \%$ in cooperatives and 3\% in mutual organizations. Social economy entities are present in almost every sector of the economy, such as banking, insurance, agriculture, craft, various commercial services, health and social services, provision of employment and sheltered workshops etc. There have been some changes in the areas of economic activity of social enterprises and subjects of the social economy in general. In the late 80 -ies - early 90-ies they are mainly involved in combating unemployment and maintaining high standards of social services under severe constraints of public finance (Mair, J., Marti, I., 2006, p. 36). The survey conducted in 2012 by the SELUSI - research consortium (funded through the 7th Framework Programme of the European Commission) that studies the market behaviors and organizational design decisions of about 600 social enterprises throughout Europe, shows that the range of areas of social enterprises becomes much wider (see Table 1).

Table 1. The fields of activity of social enterprises in Europe

\begin{tabular}{|l|c|}
\hline \multicolumn{1}{|c|}{ Fields of activity } & $\begin{array}{c}\% \text { to total number of } \\
\text { entities surveyed }\end{array}$ \\
\hline Social services & $16.7 \%$ \\
\hline Employment and training & $14.9 \%$ \\
\hline Environment & $14.5 \%$ \\
\hline Education & $14.5 \%$ \\
\hline Economic, social and community development & $14.3 \%$ \\
\hline Culture, the arts and recreation & $7.1 \%$ \\
\hline Health & $6.9 \%$ \\
\hline Housing & $2.7 \%$ \\
\hline Business associations & $2.0 \%$ \\
\hline
\end{tabular}

\begin{tabular}{|l|l|}
\hline Law, advocacy and politics & $1.6 \%$ \\
\hline Other & $4.7 \%$ \\
\hline
\end{tabular}

Source: SELUSI data including all observations across all countries $(\mathrm{N}=581)$; European Economic and Social Committee (2013).

The role of social enterprises in spurring innovation, especially social ones has been recognized and reflected in strategic document of European Commission, launched in 2011 and named "Social Business Initiative. Creating a favorable climate for social enterprises, key stakeholders in the social economy and innovation" where is declared, in order to promote a highly competitive social market economy, the Commission "...has placed the social economy and social innovation at the heart of its concerns" (European Commission, 2011, 24, p. 2). Later the European Economic and Social Committee (EESC) has clarified the main actions of the Initiative: improving access to funding; increasing visibility of social entrepreneurship; improving the legal environment. To further unlock the potential of this sector, the EESC calls for a supportive environment for social enterprises and for their better integration into all EU policies. In doing that partnerships with regional and local authorities, as well as social entrepreneurs themselves will play an important role (European Economic and Social Committee, 2014).

The experience of the European Union, US and other OECD countries shows that social enterprises perform important functions for socioeconomic development through:

- contribute to the development of local economy and society, offering certain opportunities for job creation and new forms of entrepreneurship and employment;

- help overcome social isolation (due to their possible activities for employment of handicapped or people with mental disabilities; those who been unemployed for a long time; former criminals and others); stepping up participation and voluntary work of citizens, thus strengthening the unity of the community;

- contribute to the development of a wide range of social services that are necessary for local society, but that have no interest for business as usual (low-profit, activity connected to significant costs for personnel special training so on);

- reduce the burden on local budgets in solving social problems;

- improving the structure of social programs in the region. 
By fostering of citizens' self-organization and supporting social enterprises whose activities are aimed at solving issues of communities, the local authority contributes to employment as well as selfemployment, allows to diversify the process of social services providing to the inhabitants, strengthening integrity of local societies and social capital, thus significantly reducing the level of social tension. This answers not only to a criterion of social inequality reducing, but also to the aim of decreasing possible local conflicts and increasing social safety.

Another aspect is related to the fact that, by improving the level of work inclusion through support of social enterprises, the local government has the chance to divert resources to other activities or projects, which in the opposite case would be directed on social services delivering in general or on improving the living conditions of certain disadvantaged groups of inhabitants in the community.

\section{The situation with the development of social enterprises in Poland and Ukraine}

4.1. Poland. The development of civil society and the activating of self-employment in the country got the start in the process of transition to a market economy in the 90 s of the last century. Initially, these non-governmental organizations have been functioning as charities and were not engaged in profitable business. This was due to the predominance of non-commercial approach to the organization of activities of NGOs and ensuring their funding mainly by foreign grants. As a result, until the beginning of the 21st century, organizations of the third sector have been engaged in entrepreneurial activity only in rare cases (Majdzińska, K., 2014).

In 1990 the Foundation for Social and Economic Initiatives (FISE) was created in Warsaw by people who were affiliated with the democratic opposition in the times of communist Poland. The Foundation is an independent non-profit organization. Its activity is concentrated on issues of unemployment, labor market and self-employment, including fostering the social enterprises sector. Until 2016 the FISE has realized over 150 projects, trained almost 8 thousand employees of public and private labor market institutions and published several manuals for social entrepreneurs. Since 2005, the Foundation has been animating discussions among NGOs and public administration about the development of the social economy sector in Poland, managing the biggest Polish internet portal on social economy, (www.ekonomiaspoleczna.pl), and is a member of the Standing Conference on the Social Economy (SKES). The Foundation also founded in 1994 the School of Entrepreneurship (Szkoła Przedsiębiorczości). So far the School has trained over 6 thousand people searching for employment and over 8 thousand specialists in labor market, social entrepreneurship, NGOs and public administration (see: http://www.fise.org.pl). The Polish government, along with FISE and eight other NGOs, is running a project called the Integrated Scheme for Supporting Social Economy in Poland, which will create network of organizations to assist social start-ups and other social enterprises on their way to market. The aim of the project - to improve social entrepreneurs' business skills and make the social economy stronger. The FISE and its partners are lobbying hard for a Social Entrepreneurship Act, which proposes a number of measures including a strengthening of the importance of social performance clauses in public procurement contracts, as well as tax breaks for social enterprises.

The beginning of the legal regulations related to the search of the new forms of reintegration in work of the unemployed people and those who are socially exclusive in the country, was connected with the establishment in Polish legislation the Act on the social employment of the 13th June 2003. The Act sets the definition of social exclusion, social employment, as the forms of participation in the Centers and Social Integration Clubs, and support of the work reintegration, like self-employment in the form of a cooperative. Up to 2016 in activity in the form of the social and professional reintegration service 70 centers were involved. The centers established by local communities and NGOs are financed by different sources (local and regional budgets, the Labor Fund, The State Fund for rehabilitation of the disabled, incomes from own centers activity and external sources like The European Social Fund). The type of the activities offered by the Centers included: professional trainings, practices and professional probations, assistance in searching for a job, preparation for running one's own business activity or creating the social cooperative, psychological and educational assistance for improvement of persons' professional qualification. In 2012, out of 3234 people, who graduated from the training in the Centers, 844 are now economically independent. Also this year, about 300 Social Integration Clubs have been operating. The Clubs are units offering help to individual persons and their families for reimbursement and maintain of participation in the local community's life, coming back to fulfillment 
of the roles played in the society and improvement of the professional qualities as the value on the job market (Ucieklak-jeż, P., Kulesza, M., 2014).

A lot of changes in respect to social entrepreneurship occurred during the period shortly before the Polish accession to the European Union. EU policy with corresponding funding, as well as improvements in social policy towards active form have contributed to the rapid popularization of social economy in Poland. The Act on the social cooperatives was put on effect in 2006. Its main aim is bringing back to the labor market and joint entrepreneurship people who are in danger of the social exclusion, people who have low chances for employment, as well as enabling the unemployed people to be active in their profession. The founders of the social cooperatives may be the physical persons, and the number of a cooperative workers cannot be less than 5 and not higher than 50 people (The Parliament of Poland, 2006). The Act stated the physical persons who are allowed to create the social cooperatives are:

- unemployed;

- alcohol and drug addicted, and other people with abuses after the treatment;

- homeless who realize an individual program of overcoming the homeless;

- ex-prisoners who have difficulties for social integration;

- persons with mental disorders;

- refugees who have problems with the integration;

- disabled who are able to perform the legal actions;

- other people not mentioned above, on condition that their number does not exceed $50 \%$ of the general number of the founders.

After the novelization of the Act in 2009, the social cooperative can be established by at least two legal entities from the following list: NGOs, local selfgovernments' entities or the ecclesiastical legal entities. After the establishment of the social cooperatives, the legal entities are obliged to employ at least 5 workers out of the mentioned above, within 6 months since day of registration of the social cooperative in the National Court Register. After 12 months of the continuous employment on the cooperative, employed workers can become its rightful members.

People who establish the social cooperative are allowed by the law to apply for the disposable subsidiaries from the Labor Fund resource for undertaking of the business activity, dismissal of the court charges expected while establishment of the social cooperatives, refund of the shares paid for the social insurance, tax allowances, running the simplified accounting in the cooperative, voluntary support, possibility to obtain the public task and social clause in the public orders. The activity of the social cooperative can also be supported with the funds from the budget of the local self-government units: subsidiaries, loans, services or the counseling in the financial, accounting, economical, legal and marketing extent and reimbursement of the scrutiny costs.

Social cooperatives in Poland operate in many different sectors (such as construction, catering and hotels, craft, environmental protection and tourism). The current data issued by the Polish National Council of Co-operatives (Krajowa Rada Spółdzielcza) shows that there are about 11,655 cooperatives in Poland, including those in shutdown process. Most traditional cooperatives (such as housing,manufacturing, rural agricultural, worker and bank cooperatives, cooperatives for the disabled and other types of traditional cooperatives) declined in numbers after 1989. More than $60 \%$ of all cooperatives were established before 1989. The whole cooperative sector is dominated by housing cooperatives, which represent $38 \%$ of the total number of cooperatives. Worker cooperatives constitute $8.5 \%$ of all cooperatives. Only social cooperatives, as a new type, have recently emerged in the social economy landscape, thanks to the new legislation of 2006; from then on, their number has grown dynamically. In 2007 , there were only 70 social cooperatives; by 2011, their number had increased by $470 \%$, and this unprecedented growth is still occurring. The new legislation entailed supportive measures for the start-up and operation of social cooperatives, especially in the area of job creation. However, they are subject to high risk both in terms of their membership and the lack of mechanisms supporting their operations, such as raising the quality of services, adaptation activities and access to funds for investment (most often - if not always - they have only enough money for start-up costs). Many of them are not in a position to defend themselves on the open market (Ciepielewska-Kowalik, A. et al., 2015).

Active participation in the development of social entrepreneurship undertake local self-governments. For instance, in the Malopolsky voevodship a program for development of the social economy and the creation of infrastructure for social enterprises support was adopted (Frączek, M. et al., 2010) as well as in Cracow municipality (Bohdziewicz-Lulewicz, M., Kobylec, D., 2013). 
Polish society is currently discussing the idea of an act on social entrepreneurship. Such act would include: an up-to-date definition of a social enterprise, a list of possible forms of support to such entities on the side of the state, creation of the Chamber of Social Entrepreneurs which would control the reliability of activities conducted by social economy entities. Until now, the status and activities of social enterprises haven't been legally defined. The bill was initiated in 2009 by the team dealing with solutions for the social economy sector, officially appointed by the Polish Prime Minister. The act distinguishes between two types of social enterprises. One type focuses on the work reintegration of the socially excluded. There are clear guidelines which define the required share of excluded individuals in the overall employment. The other type of social enterprise focuses on providing particular services, which are listed in the regulations. Both types must employ the socially excluded for the purpose of their social and work reintegration. Social enterprises must be registered in the National Court Register, just like any other (during discussion of the bill was proposed to transfer these functions to the Chamber of Social Entrepreneurs). The profit gained by the social enterprise must be reinvested into its social aims and its own development, or into any activity related to public benefit. At the same time, there are regulations to which a social enterprise must conform, via financial and other reporting activities. In return, social enterprises get benefits under the form of reduced property taxes, reductions of the corporate income tax and inpayments from government bodies redistributing funds for the disabled; they can also use volunteer support. Another important point is that a social enterprise must establish an advisory internal body with employees or volunteers as members, optionally involving other stakeholders such as representatives of local governments or clients. The new regulation will also allow for a variety of organizations, from joint-stock companies to associations focusing their activities on social objectives, to gain this status and operate under common conditions (Proposed Legal Act on Social Enterprise in Poland, 2011). The bill submitted to the Polish Parliament in 2011, was held hearings in several committees but has not yet been passed by the Parliament.

The Polish Government focuses on the creation of appropriate infrastructure of financial support for social enterprises. Thus, it is the ES Fund/TISE pilot program in Poland to test delivering refundable resources (loans with preferential rates) to the social economy in Poland launched. It has been established with the State-owned bank (BGK-Bank Gospodarstwa Krajowego) resources and following the guidelines established with a group of experts. The Social and Economic Investment Company TISE has been selected through BGK tender as the financial intermediary in charge of managing those resources. The ES Fund has entered into operation in 2013; it is not completed and that is why it has not been fully evaluated yet. The ES Fund is combining the principle of a loan (refundable resources) with a part of grant (preferential interest rate). This approach helps the SEs sector to accelerate its growth and above all to change its state of mind regarding financial management of the enterprise. It is a "pedagogical" way to start providing cheap loans that encourage the sector to adapt its business model for a competitive market. Moreover, it shows that the public resources can be used in a more efficient way than in the past: beyond the subsidies to afford the technical assistance cost and to provide very low interest rate, the program will allow to reuse the resources (repayments) for the 2nd cycle. Main innovation in terms of commercial offer is to gather the preferential interest rate loans and the technical assistance free of charge for the potential borrowers. It enables the social entrepreneur to have a deeply involved financial partner, who will be able to provide advice and training in each step of business development. Collecting and analysing the social impact figures of their clients is also one of the new missions under testing of the ES Fund. Final objective would be to expand this database on a long term and among clients (Social Entrepreneurship Network, 2014).

4.2. Ukraine. In last decade, the topic of social entrepreneurship becomes more common in public life and scientific research in Ukraine. A significant contribution to the promotion of social entrepreneurship in Ukraine made the Social Enterprise Support Centre set up in October 2010 at the SESP Association ${ }^{1}$, and the Resource Centre "Social Initiative" created in September $2012^{2}$. These Centres were founded under the joint initiative of the British Council in Ukraine, East Europe Foundation, PricewaterhouseCoopers in Ukraine, Erste Bank and the International "Renaissance" Foundation (the project "Development of social entrepreneurship in Ukraine"). However, administration of these centres

\footnotetext{
${ }^{1}$ http://sesp.org.ua/web/sesp/sespEN.nsf/0/BEEB3F7CAF10DA9AC225 7911005076A8

${ }^{2}$ http://socialbusiness.in.ua/
} 
and their websites was discontinued in 2013 after the termination of external financing in the framework of grant support.

During the implementation of these projects Catalogue of social enterprises in Ukraine was compiled, which includes 42 (!) entities. 7 of them enterprises created by the organizations of disabled people before the projects were started. Of the remaining 29, 35 have hybrid form - NGOs in cooperation with the individual entrepreneur. The main activities of these enterprises - trade, 5 enterprises associated with catering, 3 - sewing workshops, 4 - repair shops, 9 - interest clubs (mainly sports and recreation), 2 associated with the tourism organization. Since 2013 the Catalogue has not been updated.

Contemporary Ukrainian legislation does not provide a definition of social enterprise and does not include any specific normative acts regulating the activities of such enterprises. However, there are elements of Ukrainian law, which provide certain grounds for development of social enterprise (see: Borzaga C., Galera, G., Nogales, R., 2008, pp. 161-162). For instance, enterprises of citizens' unions can be formed in accordance with Article 112 of the Commercial Code of Ukraine and with Article 20 of the Law on Citizens' Unions for the realization of economic activities with the purpose of fulfilling their statutory goals. Nongovernmental organizations of disabled people, set up according to the Law on Principles of Social Protection of Disabled people in Ukraine can have commercial and non-commercial activities. An important element contained in Ukrainian law is that the state, territorial centres and the public have the opportunity to control the statutory social activities of communal (non-commercial) enterprises and the way enterprises' profits can be used for socially significant goals.

The survey conducted in the framework of the project "Social enterprise: a new model for poverty reduction and employment generation" concluded that Ukrainian respondents at the regional level indicated the need to improve the legislative base regulating the activities of nongovernmental organizations and to develop and adopt a specific law on social enterprises. The government organization experts, interviewed by the project, share this view. However, the representatives of international organizations interviewed during the project's survey, proposed alternative way: to amend the civil code and tax code. In general, the majority of respondents highlighted the need to introduce tax privileges to stimulate the development of social enterprises (Borzaga, C., Galera, G., Nogales, R., 2008, p. 162).

In April 2013 the Committee on Economic Policy of Verkhovna Rada of Ukraine considered the bill "On social enterprises", which was presented by the MP O. Fel'dman. According to the conclusion of the Chief scientific and expert department of the Parliament and the comments of the Committee members, the bill was rejected. I consider it appropriate to provide a citation from the expert conclusion placed on the Commission web site': "In our opinion, the use of the term "social" to determine the type of enterprise isn't relevant, so far as mentioned term describes a certain relationship of business with society, that is inherent for any business, and not associated with any organizational form of enterprise, or the activities which it deals, or with any other conditions under which one kind of enterprise can be separated from others. In addition, when one is using this definition inadvertently seems that all other enterprises are "non-social", which is not true". This quote shows that even experts of the Ukrainian parliament do not understand the concept of social entrepreneurship, to say nothing of officials at regional and local levels. Thus, official recognition of social enterprise is necessary, whether adopting a special law or amendment to the Commercial Code and relevant laws. Mr. O. Fel'dman in April 2015 again submitted the bill "On social enterprises" to the Committee on Economic Policy of Verkhovna Rada of Ukraine, while almost did not change its content (Supreme Council of Ukraine, 2015). The fate of the bill is the same as the Polish - it is pending.

The bill needs substantial revision and improvements, the basic contents of which are summarized below.

1. The bill presented to the Parliament completely ignores the fundamental principle for social enterprises recorded in the laws and regulatory documents of many countries and the European Commission. It refers to the prohibition or restriction of profit distribution for owners or shareholders of the business and reinvesting enterprises profits on its statutory social goals.

2. According to the bill, the status "social" will be assigned if an enterprise meets the following criteria:

(1) employment of persons assigned to socially vulnerable groups, if the proportion of which is at least half of the total number of employees;

${ }^{1}$ http://w1.c1.rada.gov.ua/p1s/zweb2/webproc4_1?pf3511=46025 
(2) provision of social services defined by the Law of Ukraine "On Social Services", if more than half of the recipients of those services are disabled people;

(3) provide jobs and social services to persons from socially vulnerable groups, if the share of such persons is not less than 30 per cent of total number of employees and at least 30 per cent of recipients of social services are disabled people;

(4) sell goods and services to socially vulnerable people at prices equal or below the self-cost of production;

(5) investing in socially important projects.

Firstly, the range of possible applicants for the status of "social enterprise" was significantly narrowed because number of beneficiaries is limited to only socially vulnerable people.

Secondly, this set of criteria does not fit to such important social enterprises operating in some EUmember countries, USA and Canada as the Community Economic Development Corporation (CEDC) and the Community Interest Company (CIC). The CEDC and CIC in many countries play a significant role for the socio-economic recovery of depressed areas, so they can be effective agents of economic restructuring and the restoration of social infrastructure in the regions.

Thirdly, the criterion of "investments in socially important projects" is vague and raises more questions than answers.

The bill stipulates that social enterprise status granted by the Interdepartmental Commission on public support for social enterprises suggested to be created. This corresponds to the practice of state support for social enterprises in some countries. For example, the Social Enterprise Unit operates within the British Department of Trade and Industry, also under the decision of the USA President B. Obama the White House Department of Social Innovation and Civic Participation was created. At the same time, given the declared profound decentralization of public administration in Ukraine, strengthening of local self-government and further democratization of public life, one can consider it appropriate to delegate the function of assignation of the social enterprise's status at a local level. To do this, local governments should create a public commission on social entrepreneurship in which representatives of the NGOs and social enterprises should be included. It is also needed to delegate the competence for providing various tax exemptions and preferences for social enterprises to the local level, given the fact that fiscal decentralization should pass taxes on profit as the main source of local budgets.

Article 9 of the bill provides that "members (participants) of social enterprise which is formed by joint property (property rights), having the right to participate in managing the company according to their stake (share) in the property company, unless otherwise provided statute". One keep in mind that this article does not meet the European practice of democratic management in social enterprise based on the principle of "one person - one vote". In addition, the vast majority of national legislation concerning social enterprises contains a provision that called "lock assets", under which the assets of the social enterprise is indivisible (except ones that have legal form of cooperative, limited or share company), and in a case of closing is transfer to another social enterprise.

\section{Conclusions}

In formulating recommendations for growth of the sector of social enterprises in Poland and Ukraine, it is hard not to notice that implementation will depend on a great many factors and perhaps most of all, understanding, approval and support from many social groups, individuals and institutions. A set of basic legal, political and organizational measures can help to create an appropriate environment for social enterprise development that can improve the impact of social entrepreneurship on societies in both countries. The principal requirement is to create a favourable legal context which treats social enterprises similar to business organizations, such as has been done in some developed countries, which have instituted legal frameworks to specifically support social enterprises. In doing that it is also needed to keep in mind the distribution of competences between the central, regional and local public authorities. Taking into account Poland has implemented a real decentralization of public power, as Ukraine is moving in this direction, we can conclude the following:

- The Act on Social Enterprise in Poland and Law "On social enterprises in Ukraine" should play the role of framework documents that define the essence of subject, the basic criteria and procedures for granting the status of a social enterprise to concrete entity, the main responsibility of government and regional public authorities for promoting social enterprises. Due to absence of national social enterprise concept (that is more broad than social cooperative), it will be better on the initial stage of legitimating of social enterprise to adopt the EMES European Research Network 
concept and appropriate definition criteria. This would allow having a picture, reflecting situation with social enterprises and elaborating the sector statistics eventually.

- Concerning the issues of creation, registration, closure of social enterprises these questions should be addressed in accordance to the regulatory norms relevant for the organization -legal form that was chosen by specific social enterprise (sole proprietorship, cooperative, association, foundation, mutual benefit and voluntary organizations, limited or share company);

- With respect to the social enterprises sector as an element of civic initiative, the main task of the state is not to interfere with development of spontaneous activity by citizens and by organizations and communities who are active within them. This is of high importance to maintaining the independence and autonomy of social economy entities. However, in this area, where the social enterprises should be treated as an element of the public system for solving social problems, where social enterprises are executing public policy, systemic conditions should be established (based on transparent procedures and analysis of economic and social costs and benefits) that will assure efficient and cost-effective implementation of public tasks.

- The concrete measures for social enterprises support have to be initiated by regional and local authorities based on the real opportunities for funding this support. Appropriate forms of social enterprises support can be chosen by regional and local self-governments based on their possibilities from listed below:

- Specific enabling legal, fiscal, and regulatory eco-environment might be needed for social entrepreneurs, according to the form that their initiatives take. For Ukraine region, it is needed urgently to determine such environment that is friendly for social enterprises like the Community Economic Development Corporation and the Community Interest Company.

- Public procurement measures should be developed so that social enterprises can consolidate and expand their growth.

- Support market development for social enterprise and provide training for public officials and social enterprises to deal with public tenders.

- Offering fiscal incentives to attract investors for social enterprises start-up and offering multiple forms of credit enhancement;

- Provide training and learning to social entrepreneurs and comprise social entrepreneurship in school and university curricula;

- Evaluating the impact of social entrepreneurship development in selected areas and conducting research in order to assess the different needs of the entities belonging to the social economy sector.

\section{References}

1. Bibikova, V. (2015). Social Enterprise in Ukraine, ICSEM Working Papers, 12, Liege: The International Comparative Social Enterprise Models (ICSEM) Project.

2. Bohdziewicz-Lulewicz, M., Kobylec, D. (2013). Czy Kraków będzie miał Program Rozwoju Przedsiębiorczości Społecznej? Ekonomia Społeczna, № 2 (7), pp. 94-96.

3. Borzaga C., Galera, G., Nogales, R., eds. (2008). Social enterprise: a new model for poverty reduction and employment generation. UNDP and EMES European Research Network project. Retrieved from: http://www.emes.net/uploads/media/11.08_EMES_UNDP_publication.pdf.

4. Borzaga, C., Bodini, R. (2014). What to Make of Social Innovation? Towards a Framework for Policy Development, Social Policy and Society, 13, pp. 411-421.

5. Buscaglia, F., Marini, M., Tarantola, G., eds. (2007). The Equal Community Initiative Programme. New market opportunities for social enterprises in the European Union. A handbook for social enterprises. Milan: Associazione Lavoro e Integrazione.

6. Cahalane, C. (2011). The state of the social enterprise sector in Poland. Retrieved from: https://www.theguardian.com/social-enterprise-network/2011/feb/10/social-enterprise-poland-sector.

7. Ciepielewska-Kowalik, A., Pieliński, B., Starnawska, M. and Szymańska, A. (2015). Social Enterprise in Poland: Institutional and Historical Context, ICSEM Working Papers, 11, Liege: The International Comparative Social Enterprise Models (ICSEM) Project, $32 \mathrm{p}$.

8. Defourny, J., Nyssens, M. (2010). Conceptions of Social Enterprise and Social Entrepreneurship in Europe and the United States: Convergences and Divergences, Journal of Social Entrepreneurship, 1 (1), pp. 32-53. Available at: http://msc.pef.czu.cz/msc_em/data/Jones/1213/Communication\%20J.\%20Defourny,\%20M.\%20Nyssens.pdf.

9. Defourny, J., Nyssens, M. (2013). Social innovation, social economy and social enterprise: what can the European debate tell us? / In F. Moulaert, D. MacCallum, A. Mehmood, and A. Hamdouch (ed.), The International Handbook 
on Social Innovation: Collective Action, Social Learning and Transdisciplinary Research, pp. 40-53. Edward Elgar Publishing.

10. Defourny, J., Nyssens, M. (2016). Fundamentals for an International Typology of Social Enterprise Models, ICSEM Working Papers, 33, Liege: The International Comparative Social Enterprise Models (ICSEM) Project.

11. Directorate-General for Research \& Innovation (2013). Social innovation research in the European Union. Approaches, findings and future directions / Unit B. 5 - Social Sciences and Humanities Policy Review. Retrieved from: http://ec.europa.eu/research/social-sciences/pdf/policy_reviews/social_innovation.pdf.

12. Driver, M., Porter, M.E. (2012). An Interview With Michael Porter: Social Entrepreneurship and the Transformation of Capitalism, Academy of Management Learning \& Education, 11 (3), pp. 421-431.

13. European Center for Not-for-Profit Law (2012). Legal framework for social economy and social enterprises: a comparative report. Retrieved from: http://profitpentruoameni.ro/wp-content/uploads/2012/05/LEGALFRAMEWORK-FOR-SE-FINAL-pdf.pdf.

14. European Commission (2011). Communication from the Commission to the European Parliament, the Council, the European Economic and Social Committee and the Committee of the Regions "Social Business Initiative. Creating a favourable climate for social enterprises, key stakeholders in the social economy and innovation" \{SEC(2011) 1278 final \}. Retrieved from: http://ec.europa.eu/internal_market/social_business/docs/COM2011_682_en.pdf.

15. European Commission (2013). Strengthening the social dimension of the economic and monetary union. Communication from the Commission to the European Parliament and the Council, COM (2013) 690 final. Brussels: European Commission.

16. European Economic and Social Committee (2013). Social economy and social entrepreneurship: Social Europe guide, 4. Luxembourg: Publications Office of the European Union.

17. European Economic and Social Committee (2014). Social Enterprise: Make it happen! Retrieved from: www.eesc.europa.eu/?i=portal.en.social-entrepreneurship-make-it-happen.

18. Fitoussi, J.-P., Stiglitz, J. (2011). On the measurement of Social Progress and Well Being: some further thoughts. Paper presented at the 16th World Congress of the International Economic Association, Beijing 4-8 July 2011. Retrieved from: http://www.ofce.sciences-po.fr/pdf/dtravail/WP2011-19.pdf.

19. Frączek, M., Krupnik, S., Osiborska, K., Pacut, A., Szczucka, A. (2010). Monitoring przedsiębiorstw społecznych w Małopolsce. Raport z badań [Monitoring of social enterprises in Malopolsky voevodship. Research report], Centrum Ewaluacji i Analiz Polityk Publicznych UJ i Fundacja Gospodarki i Administracji Publicznej]. [in Polish].

20. Grisolia, F., Ferragina, E. (2015). Social Innovation on the Rise: yet another buzzword in times of austerity? Salute $e$ Società, 1, pp. 169-179.

21. Kaderabkova, A. (2013). Social enterprise - social innovation, UNCE Expert Opinions. Retrieved from http://www.unece.org/info/media/expert-opinions/opinions/2013/social-enterprise-a-social-innovation.html.

22. Kolot, A., Herasymenko, O. (2016). A deficit of decent work as a current trend in the development of social and labor sphere in Ukraine, Knowledge and Performance Management, 1 (1), 1 (1), pp. 6-18.

23. Kusa, R. (2012). Social Entrepreneurship in Poland: A Preliminary Comparison of Research Approaches, Advanced Research in Scientific Areas, 3 (7), pp. 94-97, International virtual conference, Section 1: Business Management. Retrieved from: http://www.arsa-conf.com/archive/?vid=1\&aid=3\&kid=60101-259\&q=f1.

24. Mair, J., Marti I. (2006). Social Entrepreneurship Research: A Source of Explanation, Prediction, and Delight, Journal of World Business, 41 (1), pp. 36-44.

25. Majdzińska, K. (2014). Aid and support for the social economy in Poland. The case of social cooperatives CIRIEC Working paper N 2014/11. Retrieved from: http://www.ciriec.ulg.ac.be/wp-content/uploads/2015/08/WP14-11.pdf.

26. Mendell, M. (2007). Social enterprises in OECD Member Countries: What are the financial streams? Presented in Bucharest, Romania13 June 2007. Retrieved from: http://www.oecd.org/dataoecd/55/44/38870519.pdf.

27. Nicholls, A., ed. (2006). Social Entrepreneurship: New Models of Sustainable Social Change, Oxford University Press, 2006, $347 \mathrm{p}$.

28. OECD (2010). SMEs, Entrepreneurship and Innovation, OECD Publishing, Paris. Retrieved from: http://www.oecdilibrary.org/industry-and-services/smes-entrepreneurship-and-innovation_9789264080355-en; jsessionid=2x5r8dhtgpjd5.x-oecd-live-02? citeformat=ris.

29. OECD (2013). Job creation through the social economy and social entrepreneurship. OECD Publishing. Paris. Retrieved from: http://www.oecd.org/cfe/leed/130228_Job\%20Creation\%20throught $\% 20$ the\%20Social\%20Economy\%20and\%20Social\%20Entrepreneurship_RC_FINALBIS.pdf.

30. Porter, M.E., Kramer, M.R. (2011). The Big Idea: Creating Shared Value. Rethinking Capitalism, Harvard Business Review, January/February. Retrieved from: http://hbr.org/2011/01/the-big-idea-creating-shared-value/ar/pr.

31. SEKN (2006). Effective Management of Social Enterprises. Lessons from Businesses and Civil Society Organizations in Iberoamerica / a collaborative research project of the Social Enterprise Knowledge Network, Harvard University Press, 315 p.

32. Quak, E. (2013). Social enterprises: catalysts of economic transition? The potential of social enterprises to generate socioeconomic change, The Broker: a think net on globalization and development. Retrieved from: http://www.thebrokeronline.eu/Articles/Social-enterprises-catalysts-of-economic-transition. 
33. Proposed Legal Act on Social Enterprise in Poland (2011). Ustawa o przedsiębiorczości społecznej i przedsiębiorstwie społecznym - projekt roboczy z dnia 22.06.2011r. Retrieved from: http://www.ekonomiaspoleczna.pl/files/ekonomiaspoleczna.pl/public/akty_prawne/ustawa_es.pdf [in Polish].

34. Social Entrepreneurship Network (2014). Financial eco-system for social entrepreneurship: final report of the peer review meeting in Warsaw, 10-11 April 2014. Retrieved from: http://socialeconomy.pl/sites/default/files/ files/Financial_Eco-system_Final_Report.pdf.

35. Sotula, O.V. (2013). Sotsial`ne pidpryiemnitstvo yak innovatsiyna model rozvitku ekonomiki [Social entrepreneurship as an innovative model of economic development]. Efectyvna ekonomika [The Effective Economy], 4. Retrieved from: http://www.economy.nayka.com.ua/?op=1\&z=1988 [in Ukrainian].

36. Spear, R., Defourny, J., Favreau, L., Laville, J.-L., eds. (2001). Tackling Social Exclusion in Europe. The Contribution of the Social Economy, Aldershot: Ashgate.

37. The Parliament of Poland (2006). Ustawa z dnia 27 kwietnia 2006 roku o spółdzielniach socjalnych [The Act of 27 April 2006 on social cooperatives], Dziennik Ustaw, Nr 94, poz. 651 z późn. zm [Journal of Laws, No. 94, item 651, as amended, in Polish].

38. Supreme Council of Ukraine (2015). Pro sotsialni pidpriemstva. Proekt zakonu vyd . 04.23.2015 p. N 2710. Avtor zakonodavchoï initsiativi: narodny deputat Fel'dman, O.B. [On social enterprises. The draft law of Ukraine of 04.23.2015 p. $\mathrm{N}$ 2710. Author of legislative initiative: MP Fel'dman, O.B.] Retrieved from: http://search.ligazakon.ua/1_doc2.nsf/link1/JH23A00A.html [in Ukrainian].

39. Ucieklak-jeż, P., Kulesza, M. (2014). The development of the social entrepreneurship in Poland. Retrieved from: http://www.ef.umb.sk/konferencie/sev_2014/pdf/Ucieklak-Jez,\%20Kulesza.pdf. 